\title{
The Italian Antiracist Movement Between Advocacy, Service Delivery, and Political Protest
}

\begin{abstract}
The Italian antiracist movement is a composite political entity that has expressed the views, concerns, and political protests of various institutionalized and noninstitutionalized constituencies. In recent years, this movement has mainly taken a defensive stand because in the mind of many Italians "race" is associated with migration, which, in turn, is associated with crime, ethnic rivalry, and illegality. The movement has focused on affirming the primacy of human rights and individual responsibility in the face of a political system that has often yielded to negative stereotypes in order to exploit emerging political opportunities for the populist right. In addition, the movement has been active in particular policy fields where racial discrimination is more likely to occur, such as housing policy, education, sports, health policy, and practices in the job market.

This article reviews the role and impact of the main actors of the antiracist
\end{abstract}

Carlo Ruzza (MA SUNY, Ph.D. Harvard) teaches ethnic relations at the University of Leicester, UK. His research interests focus upon antiracism, populism, and ethnonationalism, civil society, Europe, and social movements. Address correspondence to: Carlo Ruzza, Dipartimento di Sociologia e Ricerca Sociale. Piazza Venezia 41- 38100 Trento, Italy; e-mail: carlo.ruzza@soc.unitn.it.

The author thanks the following funding organizations, which supported the empirical work for this article: The European Union-DG Research, which funded the projects Organized Civil Society and European Governance (CIVGOV 2003-6) and Institutional Patterns of Race Discrimination (XENOPHOB 2003-6). The work on migrant associations with particular reference to the health policy fields w $=$ ported by the Volkswagen Ffoundation grant Giving New Subjects a Voice (2005-8) $\overline{\overline{\bar{v}}}$ hs to Giulia Bigot for her help with the interviews. 
movement in terms of its structure and composition, its campaigns, and its activities. It argues that facing hostile public opinion, and interpreting the grievances of socially and politically weak groups of recently arrived migrants, it has learned to rely on the generalist associational resources of the leftist and Catholic conscience constituencies. It has formed a broad and articulated antiexclusionary advocacy coalition.

Issues of racial and xenophobic discrimination, which have been relevant in Northern Europe for several decades, are now also prominent in Southern Europe where ethnic diversity is growing through increasing migration flows. While throughout Europe conflicts related to ethnic diversity have sparked a reexamination of the meaning of territorial belonging, citizenship, and nationality, and have stimulated a broad range of responses by social and political institutions, South European countries have only recently begun to react to the politicization of migration-related issues. One such reaction is the emergence of distinct antiracist organizations paralleled by antidiscrimination and promigrant campaigns supported by the left-liberal family of social movements, mainstream leftist parties, churches, and voluntary organizations.

This article examines the conditions for its emergence and its political opportunities in the current political and social context. Evidence for the article comes from a variety of sources. In 2003-5, interviews were conducted with key Italian government officials at various levels of government and with representatives of antiracist organizations in five cities on the role, strategies, and political opportunities of antiracist movements in the policy process. Fourteen formal interviews with representatives of antiracist groups were conducted in Milan, Udine, Bologna, Naples, and Cagliari-selected to represent the variety of geographical and economic specificities of the country. The interviews focused on activists' perceptions of institutional support and support by the population, their identification of discrimination in different policy sectors and particularly in relation to housing and labor market policies.

\section{Demographic, Economic, and Political Context}

Southern Europe as a whole, and within it Italy, have seen substantial migration flows in recent years. In contrast to Northern Europe, this migration is characterized by the multiprovenance of migrants and their illegal status. It occurs at a time when economic globalization engenders increased competition in the Italian labor market and a redefinition of employment patterns in favor of increasingly irregular, often illegal forms of employment. In this context, rapidly increasing immigration has deeply shocked a country with no significant colonial past and therefore little experience of ethnic diversity. The limited ability of the Italian state to control its territory, typical of all South European states, the prevalence of organized gangs of human traffickers, and the objective difficulty of controlling a very long coastline 
meant that illegal migration escalated rapidly in the late 1980s and 1990s, spurring fears of crime but also engendering feelings of cultural displacement in the population.

These factors shaped the focus of both antimigrant and antiracist movements. Antiracist mobilization has focused only secondarily on issues of "race." While combating media stereotyping of migrants, it has emphasized migrants' human rights or justified their access to services, political representation, and/or territorial belonging. The issue of biological "race" remains significant in some limited contexts and for some ethnic groups, not least because many migrants are nonwhite, but it is not the main issue. Rather, antiracist mobilization focuses on (1) reversing the exclusionary conceptualizations in various arenas in a state whose funding principles are largely based on a monoethnic model; and (2) counteracting the perception of ethnic rivalry.

The issue of racism emerged at a time when the foreign population increased at a rapid rate in the 1980s and 1990s in the relatively weak states of Southern Europe that had high unemployment rates and levels of political corruption, and a substantial informal economy of 25 percent f aross national product (Venturini 2004). As in these countries, in Italy as wel of a "war among the poor" (ibid.). In 1945, having rejected racial discrimination, which permeated institutions under Fascism, most Italians were not ready to readopt compromised biological racist stereotypes. Even the political right eschewed their use. The Italian lore was to maintain "we are not racist." Or even "we are not racist because we have been discriminated against ourselves." Nonetheless, intolerance and institutional discrimination toward foreign migrants emerged quickly in several parts of the country, combining with that directed against internal migrants who had come to the north from the south of Italy in the 1980s-1990s (Sniderman, Peri et al. 2000). As the flow of migrants continued, new stereotypes emerged-they manifested themselves in the media and in political discourse (Dal-Lago 1999). While some political actors exacerbated negative sentiments against migrants, public responses were less vehement. Two dominant frames emerged: migration as a threat to jobs and migration as a threat to security.

These frames resonated with the population, which was very concerned with joblessness and personal safety and less with "race." A 1999-2000 survey found that Italians accept people of other "races" as neighbors slightly more than they accept immigrants. At around 15 percent this figure is roughly midway in a distribution of twenty-eight European countries (Arts and Halman 2005: 87). However, both in 1990 and in 1999-2000, more than 90 percent of the Italian population sampled believes that in case of job scarcity, employers should give priority to co-nationals rather than to migrants (ibid.: 89). This figure is the highest in a distribution of twenty-nine countries, and the fact that it remained constant in the two different surveys ten years apart (1990 and 2000) indicates fairly well-ingrained attitudes.

The antiracist movement emerged as a response to a period of right-wing political success. Before the collapse of the first republic in the early 1990s, the Italian 
political culture, split as it was between two universalisms - the Communist and the Catholic-refused to make political use of internal ethnic rivalries. With the collapse of the party system following a set of corruption scandals, the situation changed. Capitalizing on and fueling ethnic tensions, the ethnonationalist movement Northern League began to acquire electoral support by thematizing and politicizing a Northern-Italian territorial identity that was previously merely cultural. As internal migration abated, the language of ethnic discrimination changed. Parties of the right profited from the fears engendered by migration. A content analysis of party documents reveals an increasing negative focus on migration over the past decade (Fella and Ruzza 2006).

The center-left government in 1998 approved a framework law to regulate migration policy: the Turco-Napolitano law, which instituted special temporary holding camps (centri di permanenza temporanea, CPTs), to detain illegal immigrants. These centers, which emerged as one of the largest topics of mobilization, reveal how even the left was sensitive to an alarmist political climate. Nonetheless, at the same time, the Turco-Napolitano law included new provisions to combat racial discrimination, and instituted a number of consultative fora of associations representing the rights and interests of immigrants. After the 2001 election the center-right replaced the center-left government and took a more exclusionary stand on migration-related issues. A new law on immigration was introduced, the Bossi-Fini law, which attempted to clamp down on clandestine immigration and tied legal immigration to the possession of employment contracts.

All these factors created a context in which the antiracist movement found it difficult to mobilize.

\section{Antiracist Mobilization}

A bloc of antiracist associations has emerged in several EU countries. In the core European countries, they often grew out of smaller migrant associations and formed a movement against racist attacks. In Southern Europe they often developed from multipurpose nongovernmental organizations or within leftist political parties or social organizations. The core European countries with a colonial past imposed their language on and granted citizenship to their nonwhite citizens. Nevertheless, discrimination constitutes a severe problem even for the children and grandchildren of these citizens. Antiracist formations emerged as a reaction to this discrimination. They rely on differentiated action repertoires, ranging from the strategic use of the vote, to lobbying and advocacy activities, to political protest, and occasionally other forms of disruptive action. After years of institutionalization, in recent years disaffected youth have again taken to the streets of several core European capitals in often violent urban protests. These episodes presuppose a relatively socially skilled population with an ability to collaborate at least in staging contentious events, if only at a basic level.

The situation is more difficult for antiracist mobilization in Southern Europe, 
since political opportunities are more restricted. Immigrants come from a wide range of countries, are often illegal and as such they do not have access to political rights or vote. For them public protest activities are high-risk strategies that can cause expulsion from the country. As they often do not speak the host language, coordinating strategies with allies, sympathetic institutional actors, and other social movements remains difficult. Coordinating activities is difficult even among migrants living in the same area since they speak many different languages. Since their religions differ, they cannot utilize churches as shared meeting points. They might have different and sometimes incompatible problems, principles, and claims. Finally, they are also often territorially dispersed. Despite discrimination, they find it difficult to mobilize. Their situation epitomizes the "poor people's movements," which do not have the political skills, organizing ability, and resources to engage in viable protests (Piven and Cloward 1978).

Migrants in Southern Europe live and work in much poorer societies and are themselves poorer than many autochthonous citizens. Struggling to find employment often becomes an all-absorbing activity that leaves no time for any form of political participation, contentious or noncontentious. Associations of migrants are also too weak to function as stepping-stones for social movements. Nonetheless, a conscience constituency of institutional activists and allies has emerged to oppose racial discrimination, improve quality of life, and promote the social recognition and political representation of migrants. To sum up, in South European societies there are many obstacles to migrant self-mobilizing. Antiracist movements have emerged even in these difficult conditions, but they tend to be restricted in terms of political opportunities, media visibility, and possibly outcomes.

We find the same pattern in Italy. A hostile political climate, worries about ethnic rivalry on the job market, and security-related fear of migrants have weakened the appeal of the movement in the population. As public opinion turned more antimigrant, however, new opportunities were opening at both national and supranational levels of the antiracist movement. After the prospects of the Italian antiracist movement deteriorated during the right-wing government (2001-6), which suspended all national-level consultation forums and seemed barely interested in interacting with migrants and their representatives, and since the 2006 election of the Prodi center-left government, responsiveness to antiracist associations has improved. Perhaps even more important: the approval of article 13 of the Amsterdam Treaty and the two antiracist directives were eventually incorporated in Italian legislation (Ruzza 2006). This handed a new powerful tool to antiracist organizations and their institutional sympathizers. In particular, in connection with the approval of the two "race directives," a new service, the National Office Against Racial Discrimination (UNAR) was formed to collect grievances and act upon them through the new laws. After the formation of UNAR, antiracists had an institutional interlocutor that could process their grievances and requests. A number of pro-immigrant associations also formed to defend immigrants against racism and discrimination and to promote their social integration. 


\section{Antiracist Actors, Their Action Repertoires, and Their Opposition}

Italian antiracist movements neither $\overline{\overline{\bar{\nu}}}$ often for policy changes nor support their requests by threatening disruptive action. There is not enough support in the population and therefore little approval of contentious politics among activists. Nevertheless, some protest events occur and groups oriente For instance protests have mainly in large cities.

In large cities such as Milan and Naples contentious repe more attainable and are therefore utilized by at least some org size cities, such as Udine and Bologna, promigrant organiz contentious repertoires, also as a matter of principle. The $\mathrm{k}$ who glorified the distinct fact is found in the frequent interaction between actifists fr local Veneto 'race'. background with third-sector personnel and volunkeers, wh However, the left has also repertoire (Tilly and Tarrow 2007).

Contentious episodes have occurred in reaction to sor occurred in 2002 in Treviso against racist statements of the Lega mayor Gentilini on occasions sparked right-wing local authorities, especially in the northeast of protests. Northern League has its electoral basis. Hor instance, organized protests have occurred in Padua in the past few years in response to the building by a right-wing local administration of a three-meter metal partition to enclose a high-crime migrant housing project. ${ }^{1}$ In that context, demonstrations and other actions such as study groups, public meetings, festivals, and petitions took place.

As most actions occur at the local level it is difficult to assess their frequency and relevance. Most interviewees argue that contentious actions are infrequent and often poorly attended apparently because the migrant and nonwhite population is still too concerned with the immediate goals of ensuring subsistence and housing to engage in political participation of any kind. The Italian left-liberal social movements constituency is, in principle, supportive but often not prepared to mobilize, particularly in this period of relatively low overall movement mobilization. Also, many left-liberal movement activists are aware that contentious actions would not be well received by the population. Conversely there are small groups of leftist and anarchists, often based in city-based "social centers," that reject the ideology of participation and advocate hard protest. They constitute a minority voice in the movement.

The core of the movement is constituted by promigrant associations. A study in 2001 revealed that there were 900 associations operating on behalf of immigrants/ non-Italian citizens in Italy, including 750 promoted by foreign nationals and 150 by Italian activists acting on their behalf (Vicentini and Fava 2001 [cited in Caponio 2005]). Migrants' own associations were weak, fragmented, small-scale and nonprofessional, devoting their energies to cultural initiatives rather than political mobilization. They were hardly representative of the migrant population-smaller migrant groups with higher cultural capital formed more associations than larger groups, especially if these were not Catholic and received less help from the Catholic Church: there is a higher proportion of Middle Eastern and African associations 
staffed by students and refugees than there are Chinese associations - a group whose many members are unskilled and whose familist culture hinders associationism (Caponio 2005: 933). Associations that promote the rights of migrants are dominated by those led by white ethnic Italians, particularly those linked to the trade unions and the Catholic Church. The Catholic association, Caritas, is the most influential and prominent organization working with immigrants, and is highly active both at the national and local levels in organizing a range of social assistance provisions. Our own interviews indicated that antiracist organizations are engaged in a variety of mainly sensitizing campaigns, primarily at the local level.

At the national level, the Italian antiracist movements have occasionally unified in their countermobilization against xenophobic movements, such as the Northern League (Ruzza 2004). Large associations are involved in broader antiracist activities and campaigns to raise awareness of the problems endured by immigrants. Among the few unified national campaigns, one can cite an unsuccessful campaign in the late 1990s titled "From Guests to Citizens," which included a petition to facilitate the acquisition of Italian citizenship. This campaign integrated a host of organizations, such as peace groups like Lunaria and antiracist groups such as European Network Against Racism (ENAR), as well as political parties, such as the Communist Refoundation Party. National-level events are organized by the Italian representation of ENAR, organizations such as CESTIM and Lunaria, which promotes research on immigration issues and campaigns on racism, awareness-raising activities, and intercultural training, and the Association of Juridical Studies on Migration-a voluntary association of legal professionals providing legal advice and assistance to immigrants and training for those working with them, promotes research and study on the legal problems facing immigrants and lobbies for changes in the law on immigration.

At the local level, resource-poor associations find it hard to get involved in largescale coordinated campaigns. They are often mainly oriented to service delivery, often on behalf of local authorities. Many such associations are dependent on public funding, therefore making it difficult to challenge decision makers openly. Instead they seek to influence decision makers through their regular institutional contacts. Caritas and the Catholic associations linked to it enjoy a more privileged relationship with decision makers (having connections both to center-right and center-left former Christian democrat parties) and enjoy greater opportunities to lobby decision makers. Other local-level associations tend to be more preoccupied with local cultural initiatives for migrants.

Local actors that are branches of national associations or members of umbrella organizations tend to get more involved in broader political campaigns related to the national policymaking sphere. For example, Caritas branches provide services for immigrants at the local level while producing authoritative research and statistical studies on the experience of immigrants in Italy at the national level. Representing and enjoying a privileged position, they are esteemed by Catholics on the right and left. The National Association Beyond Frontiers (ANOLF)_linked to the Confed- 
eration of Italian Workers Trade Union-with branches throughout Italy, acts as an advocate of immigrant rights, promoting cultural activities and information and training for immigrants and those working with them.

In particular, organizations connected to the trade unions (e.g., ANOLF in Naples, the Association of Friuli emigrant workers in Udine) or to the left and the social centers (e.g., the Recreational Italian Communist Association [ARCI] in Cagliari, the Association for Foreign and Nomads Support in Milan) became involved in broader campaigns - for example, protest actions against the government's immigration policies and more specific local initiatives against CPTs.

Still at the local level we find campaigning for greater openness of EU borders to migrants, a campaign of information on the consequences of the Bossi-Fini law, a campaign of "Mobilization Against the Opening of Illegal Immigrant Detention Centers in Milan," a continuing initiative to provide support and information offices for migrants in most cities of the Friuli Venezia Giulia region and support for migrant rights protection (continuing since 1987), support for a project titled "Project Equal: Ethnos and Ethos," a campaign to provide information on bursaries for non-European migrant students, a campaign to promote the right to vote at the local level, campaigns of groups working within schools to promote intercultural education, and so on. As we see, the range of activities is wide, some activities are oriented to the public sphere, others to specific public policies. Much work has been done in the fields of education, health, housing, employment, and the justice system. In each of these areas a set of changes has taken place over past decades, redefining the actors, political opportunities, and action repertoires of antiracist social movements.

\section{Administrative Bias and the "Second Generation" Challenge}

Caponio's fieldwork on three cities (Naples, Milan, and Bologna) suggests that administrations prefer to interact with large generalist promigrant organizations staffed by Italians rather than migrant-run organizations (Caponio 2005). This might change as a second generation of migrants goes through the education system and will reach adulthood in a few years. This is particularly the case for the larger migrant communities: people from Albania, Morocco, Romania, China, and the Philippines. Thus, a dialogue about combating discrimination has developed between representatives of the promigrant wing of generalist voluntary associations mainly at the local level (Caponio 2005), and particularly in the areas ruled by left-wing local governments with a history of constructive collaboration between progressive local governments and the political representatives of the Catholic and ex-communist subcultures. Solid relations of collaboration between likeminded social and political actors, reelected by a stable vote, have often thrived over the years. The antiracist organizations left outside these local dialogues face greater obstacles.

Our own interviews point to a split between the institutionalized and dominant wing of the movement, which includes the Christian Association Italian Workers, 
a large Catholic association and ARCI, an ex-communist youth association, on the one hand, and a set of smaller antiracist associations, which are fairly isolated from policymakers, on the other. Apparently, several small antiracist associations found their dialogue with policymakers too limited - and saw its activities increasingly oriented to the public sphere and focused on sensitizing of the local population through the diffusion of information on discrimination, and also the organization of petitions and other protest events.

\section{Conclusions}

This article argued that in the Italian context both conflict and cooperation are available options. There is not an alternative between disruption and institutionalization but both strategies can be pursued at the same time. We found that movement-related associations interact with sympathetic parts of the state and social institutions in a concerted effort to diffuse antiracist values and to affect policy. In all contexts, civil society associations perform distinctive roles: they focus on improving policies, opposing exclusionary policies and actors, constructing an autonomous public sphere that is more open to a plurality of cultural expressions. However, we found that a minority of actors disagree with this approach, and, favoring disruptive action, argue that the currently dominant ideology of participation can stifle dissent, engender excessive compliance with institutions, and provide undeserved legitimacy to political actors.

\section{Note}

1. See wrwglobalproject.info/art-3031.html and http://it.wikipedia.org/wiki/Muro_ di_Padova/.

\section{References}

Arts, W., and L. Halman. 2005. "National Identity in Europe Today: What the People Feel and Think." International Journal of Sociology 35, no. 4: 69-93.

Caponio, T. (2005). "Policy Networks and Immigrants' Associations in Italy: The Cases of Milan, Bologna and Naples." Journal of Ethnic and Migration Studies 31: 931-50.

Dal-Lago, A. 1999. Non Persone. L'esclusione dei migranti in una società globale <<transtation of titte? $>>$ Milan: Feltrinelli.

Fella, S., and C. Ruzza. 2006. "Breaking Old Taboos: Changing Political Opportunities and the Re-invention of the Italian right." Journal of Southern Europe and the Balkans 8, no. 2. <<page nos. of article?>>

Piven, F.F., and R. Cloward. 1978. Poor People's Movements: Why They Succeed, How They Fail. New York: Vintage.

Ruzza, C. 2004. "The Northern League: Winning Arguments, Losing Influence." Current Politics and Economics of Europe 13, no. 4: 309-34.

- 2006. "Human Rights, Antiracism and EU Advocacy Coalitions. In Sociology and Rights, ed. L. Morris, 111-28. London: Routledge.

Sniderman, P., P. Peri, et al. 2000. The Outsider: Prejudice and Politics in Italy. 
Princeton, NJ: Princeton University Press.

Tilly, C., and S. G. Tarrow. 2007. Contentious Politics. Boulder, CO: Paradigm.

Venturini, A. 2004. Postwar Migration in Southern Europe, 1950-2000 An Economic Analysis. Cambridge: Cambridge University Press.

Vicentini, A., and T. Fava. 2001. Le Associazioni di Cittadini Stranieri in Italia <<translation of title?>>. Venice: Fondazione Corazzin. 